\title{
Revealing the Role of the Calcineurin B-Like Protein-Interacting Protein Kinase 9 (CIPK9) in Rice Adaptive Responses to Salinity, Osmotic Stress, and $\mathrm{K}^{+}$Deficiency
}

\author{
Sergey Shabala $1,2, *,+\oplus$, Mohammad Alnayef ${ }^{2,+}$, Jayakumar Bose ${ }^{3}$, Zhong-Hua Chen ${ }^{4}$, Gayatri Venkataraman ${ }^{5}$, \\ Meixue Zhou ${ }^{2}$, Lana Shabala ${ }^{2}$ and Min Yu ${ }^{1, *}$ \\ 1 International Research Centre for Environmental Membrane Biology, Foshan University, \\ Foshan 528000, China \\ 2 Tasmanian Institute of Agriculture, University of Tasmania, Hobart, TAS 7005, Australia; \\ m-nayef@hotmail.com (M.A.); meixue.zhou@utas.edu.au (M.Z.); L.Shabala@utas.edu.au (L.S.) \\ 3 Australian Research Council Centre of Excellence in Plant Energy Biology, School of Agriculture, \\ Food and Wine, University of Adelaide, Glen Osmond, SA 5064, Australia; jayakumar.bose@adelaide.edu.au \\ 4 Hawkesbury Institute for the Environment, Western Sydney University, Penrith, NSW 2751, Australia; \\ Z.Chen@westernsydney.edu.au \\ 5 Plant Molecular Biology Laboratory, M.S. Swaminathan Research Foundation, Chennai 600113, India; \\ gayatri@mssrf.res.in \\ * Correspondence: Sergey.Shabala@utas.edu.au (S.S.); yumin0820@hotmail.com (M.Y.)

Citation: Shabala, S.; Alnayef, M.; Bose, J.; Chen, Z.-H.; Venkataraman, G.; Zhou, M.; Shabala, L.; Yu, M. Revealing the Role of the Calcineurin B-Like Protein-Interacting Protein Kinase 9 (CIPK9) in Rice Adaptive Responses to Salinity, Osmotic Stress, and $\mathrm{K}^{+}$Deficiency. Plants 2021, 10, 1513. https://doi.org/10.3390/ plants10081513

Academic Editors: Dorina Podar and Stanislav Isayenkov

Received: 23 June 2021

Accepted: 19 July 2021

Published: 23 July 2021

Publisher's Note: MDPI stays neutral with regard to jurisdictional claims in published maps and institutional affiliations.

Copyright: () 2021 by the authors. Licensee MDPI, Basel, Switzerland. This article is an open access article distributed under the terms and conditions of the Creative Commons Attribution (CC BY) license (https:// creativecommons.org/licenses/by/ $4.0 /)$.
Abstract: In plants, calcineurin B-like (CBL) proteins and their interacting protein kinases (CIPK) form functional complexes that transduce downstream signals to membrane effectors assisting in their adaptation to adverse environmental conditions. This study addresses the issue of the physiological role of CIPK9 in adaptive responses to salinity, osmotic stress, and $\mathrm{K}^{+}$deficiency in rice plants. Whole-plant physiological studies revealed that Oscipk9 rice mutant lacks a functional CIPK9 gene and displayed a mildly stronger phenotype, both under saline and osmotic stress conditions. The reported difference was attributed to the ability of Oscipk9 to maintain significantly higher stomatal conductance (thus, a greater carbon gain). Oscipk9 plants contained much less $\mathrm{K}^{+}$in their tissues, implying the role of CIPK9 in $\mathrm{K}^{+}$acquisition and homeostasis in rice. Oscipk9 roots also showed hypersensitivity to ROS under conditions of low $\mathrm{K}^{+}$availability suggesting an important role of $\mathrm{H}_{2} \mathrm{O}_{2}$ signalling as a component of plant adaptive responses to a low-K environment. The likely mechanistic basis of above physiological responses is discussed.

Keywords: calcium signalling; potassium transport; AKT; HAK; reactive oxygen species; ABA; stomata; CBL; CIPK

\section{Introduction}

An understanding of plant responses to abiotic stress is vital for the genetic engineering of climate-resilient crops. This involves understanding the mechanisms by which plants sense stresses and generate appropriate stress-induced signals, such as changes in the cytosolic free $\mathrm{Ca}^{2+}$ and ROS [1-3]. These changes then produce what is known as the " $\mathrm{Ca}^{2+}$ signature" $[4,5]$ triggering a protein phosphorylation cascade that finally targets proteins directly involved in cellular protection, or transcriptional factors regulating stress-induced genes [6]. Salinity [7-9], drought [10,11], and $\mathrm{K}^{+}$deficiency [12] have all been shown to induce transient $\mathrm{Ca}^{2+}$ influx, thereby increasing cytosolic $\mathrm{Ca}^{2+}$ concentration. This change in the cytosolic $\mathrm{Ca}^{2+}$ levels can be detected by numerous high-affinity calcium sensors. In higher plants, several families of $\mathrm{Ca}^{2+}$ sensors have been recognised, including calmodulin $(\mathrm{CaM})$ and CaM-related proteins [13,14], $\mathrm{Ca}^{2+}$ dependent protein kinases (CDPKs) [15,16], and calcineurin B-like (CBL) proteins and their interacting protein kinases (CIPKs) [17]. 
CBL-CIPKs interactions transduce downstream signals to membrane effectors (various membrane ion channels, pumps, and transporters) which, in turn, facilitate ionic homeostasis by controlling ion uptake, long-distance transport, and sequestration [18]. Ten CBL and 26 CIPK isoforms are present in Arabidopsis, and in rice these numbers are 10 and 30 , respectively $[19,20]$. OsCIPKs genes are highly responsive to external stimuli, with $15,12,12$, and 16 OsCIPKs being induced by drought, salinity, PEG, and ABA treatments, respectively, in rice [21].

The salt overly sensitive (SOS) pathway is one of the classical examples of a CBL-CIPK signalling pathway in response to salt stress. SOS3/CBL4 has been identified as a $\mathrm{Ca}^{2+}$ binding protein [17]. In response to salt stress, the transient alleviation in the cytosolic $\mathrm{Ca}^{2+}$ concentration activates SOS3/CBL4, which then interacts with SOS2/CIPK24 to directly regulate the downstream component of SOS1, a putative $\mathrm{Na}^{+} / \mathrm{H}^{+}$antiporter, with the final result being the maintenance of low intracellular $\mathrm{Na}^{+}$[22]. The SOS3-SOS2 complex may also regulate the tonoplast $\mathrm{Na}^{+} / \mathrm{H}^{+}$antiporter, assisting in compartmentation of toxic $\mathrm{Na}^{+}$in the vacuole, thus lowering $\mathrm{Na}^{+}$concentration in the cytosol [23]. In addition, SOS2/CIPK24 may modulate the plasma membrane $\mathrm{H}^{+} / \mathrm{Ca}^{2+}$ antiporter (CAX1) to control intracellular $\mathrm{Ca}^{2+}$ homeostasis [24]. Rice OsCIPK24 and OsCBL4 were also able to activate OsSOS1 in yeast cells [25], although the beneficial effects of such activation on salinity tolerance was questioned [26].

The ability of plants to maintain cytosolic $\mathrm{K}^{+}$homeostasis is critical to confer both salinity and drought tolerance [27-29]. The CBL1/CBL9-CIPK23 complex regulates the AKT1 pathways that play a key role in $\mathrm{K}^{+}$homeostasis under water stress. A loss of function of Atcipk23 and cbl1/cbl9 results in an increased drought tolerance in Arabidopsis resulting from the mutants possessing a hypersensitivity of stomata to ABA, which in turn caused a reduction in transpiration rate [30]. In rice, OsCBL1-OsCIPK23 operates upstream of OsAKT1, and it has been reported that loss of function of Oscipk23 caused similar symptoms of $\mathrm{K}^{+}$deficiency as occurred in the Osakt1 mutant under low $\mathrm{K}^{+}$conditions. This suggested the critical role of OsCIPK23 in modulating AKT1 activity in $\mathrm{K}^{+}$homeostasis in rice plants [31]. High affinity $\mathrm{K}^{+}$uptake systems are also regulated by CBL-CIPK interaction [32].

With the large number of members of CBL-CIPK families, not all of them have been properly characterized at the functional level. One of these is CIPK9 (Locus At1G01140). In Arabidopsis, AtCIPK9 expression was ubiquitous in the mature root zone, but less pronounced in the elongation zone [33]. Moreover, its expression was inducible under abiotic stress (osmotic stress; salinity; cold) as well as under low $\mathrm{K}^{+}$conditions [33]. Atcipk9 mutant plants were hypersensitive to $\mathrm{K}^{+}$-deficient conditions [34], most likely as a consequence of impaired AtHAK5-mediated $\mathrm{K}^{+}$uptake [35]. It was also shown that AtCIPK9 interacts with tonoplast CBL2 and CBL3, to confer $\mathrm{K}^{+}$homeostasis in Arabidopsis [36]. Consistent with this, no significant difference in $\mathrm{K}^{+}$uptake or content was observed in plants cultivated both in high $\mathrm{K}^{+}(20 \mathrm{mM})$, and low $\mathrm{K}^{+}(0.02 \mathrm{mM})$ growth media [33]. Other reported roles of CIPK9 in Arabidopsis include responses to wounding [37], regulation of $\mathrm{Mg}$ homeostasis [38], and growth under high external $\mathrm{Mg}^{2+}$ conditions [39], as well as $\mathrm{NH}_{4}$-dependent root growth [40]. Although AtCIPK9 and OsCIPK9 are orthologous by phylogenetic analysis, and have about $79 \%$ of identity in protein sequences [41], the role of CIPK9 in regulation of $\mathrm{K}^{+}$homeostasis and responses to abiotic stresses in rice has never been revealed. In this study, we aimed to fill this gap in the knowledge. By conducting a range of whole-plant physiological and cell-based electrophysiological experiments, here we demonstrate that Oscipk9 rice mutant, lacking a functional CIPK9 gene, displayed a mildly stronger phenotype, both under saline and osmotic stress conditions. This difference was attributed to the ability of Oscipk9 plants to maintain significantly higher stomatal conductance. OsCIPK9 also played an important role in $\mathrm{K}^{+}$acquisition and homeostasis, with Oscipk9 roots showing hypersensitivity to $\mathrm{ROS}$ under conditions of low $\mathrm{K}^{+}$availability. 


\section{Results}

\subsection{Oscipk9 Mutant Is Mildly Salt-Tolerant}

The Oscipk9 mutant showed a significantly (by $47 \% ; p \leq 0.01$ ) higher dry weight than the wild type (WT) under control (non-saline condition) (Figure 1A,B). Its dry weight (DW) was not affected by exposure to moderate salinity $(40 \mathrm{mM})$ for 3 weeks, while WT plants showed a significant $(\sim 24 \% ; p \leq 0.05)$ decline (Figure $1 \mathrm{~B})$. More severe $(80 \mathrm{mM})$ salinity treatment caused a further reduction in plant DW that was more pronounced in the Oscipk 9 mutant. Stomatal conductance was identical for 0 and $40 \mathrm{mM} \mathrm{NaCl}$ treatments between two lines, but significantly higher in cipk9 knockout under the high saline condition (Figure 1C) compared with WT. Both lines had the same shoot osmolality under control conditions (Figure 1D) that progressively increased upon salinity exposure. At all concentrations, the osmolality was significantly $(p \leq 0.01)$ lower in the Oscipk9 mutant compared to the WT (Figure 1D). Overall, this data indicates a mildly salt-tolerant phenotype in Oscipk9 mutant.

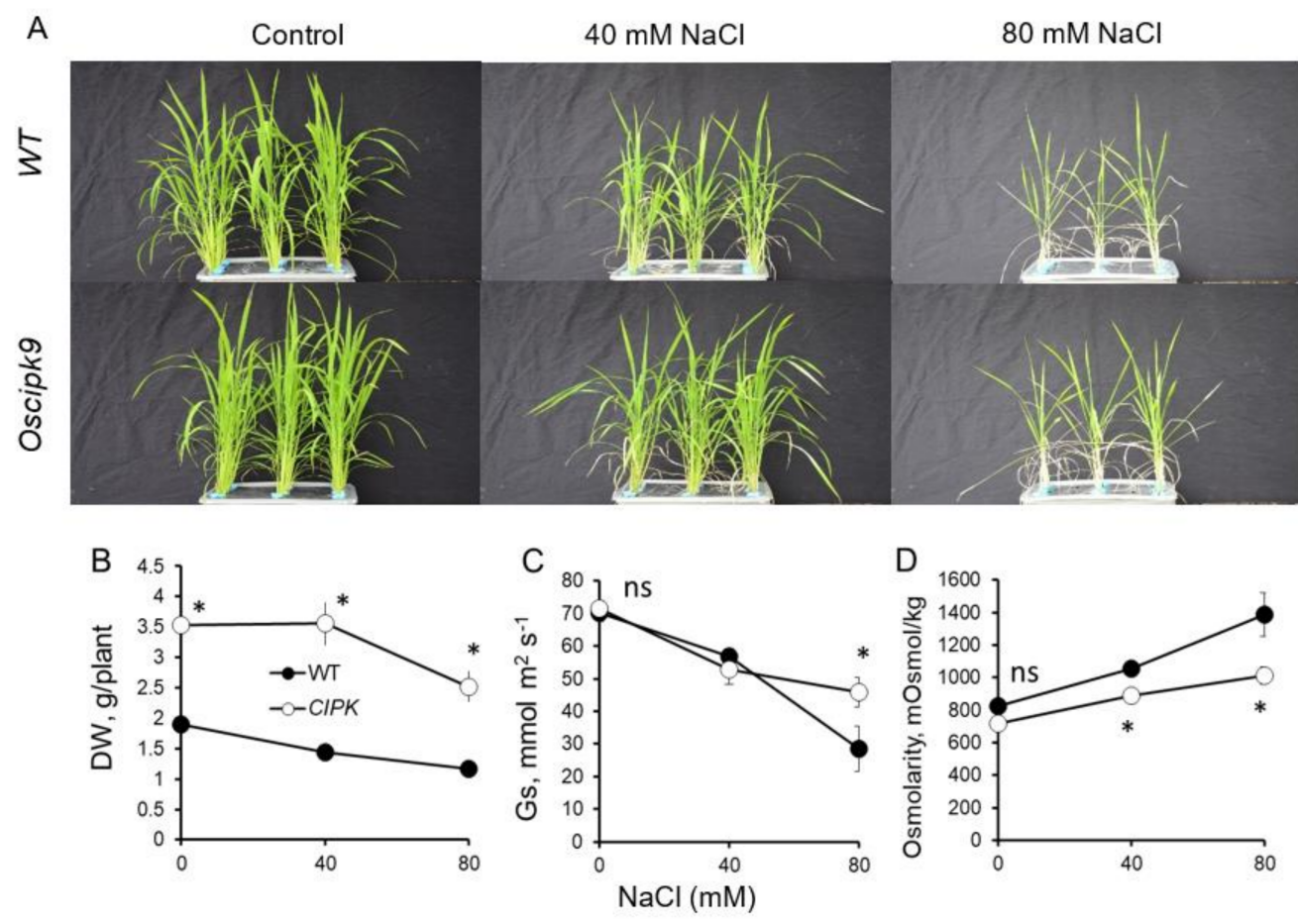

Figure 1. Effects of salinity stress on growth and phenotype of Oscipk9 and WT plants. (A) plant phenotype under control, mild ( $40 \mathrm{mM} \mathrm{NaCl}$ for 3 weeks) and severe $(80 \mathrm{mM} \mathrm{NaCl})$ treatments; (B) plant dry weight; (C) stomatal conductance; and (D) shoot osmolality. Closed circles-WT; open circles-Oscipk9 mutant line. Data are the mean \pm SE $(n=18)$. Asterisk denotes significant difference between WT and cipk9 plants at $p<0.05$.

Oscipk9 mutant had a similar shoot $\mathrm{Na}^{+}$(Figure 2A) but much lower (by $43 \%$; significant at $p \leq 0.01$; Figure 2B) $\mathrm{K}^{+}$content in the shoot when grown under the non-saline control condition, compared with WT. Exposure to salinity for 3 weeks altered both the $\mathrm{Na}^{+}$and $\mathrm{K}^{+}$content in both shoots and roots, in both lines. Under moderate salinity, the shoot $\mathrm{Na}^{+}$content gradually increased, but was not significantly different between the lines (Figure 2A), while the shoot $\mathrm{K}^{+}$content was not affected and remained similar to the control level (Figure $2 \mathrm{~B})$. Severe $(80 \mathrm{mM} \mathrm{NaCl})$ salinity treatment reduced $\mathrm{K}^{+}$content in Oscipk9, but not in WT shoots (Figure 2B). Shoot $\mathrm{Na}^{+}$content was slightly higher in WT but not significantly $(p<0.05)$ different under severe salinity treatment. No significant differences were detected in root $\mathrm{Na}^{+}$and $\mathrm{K}^{+}$contents between the lines under the non-saline condition (Figure 2C,D). The dose-dependent increase in root $\mathrm{Na}^{+}$content was reported for Oscipk9 plants, while in WT root $\mathrm{Na}^{+}$has "stabilized" at around $150 \mathrm{mM}$ level and did not increase with increasing salinity (Figure $2 \mathrm{C}$ ). Root $\mathrm{K}^{+}$content declined in both lines 
in a dose-dependent manner, with no clear difference between Oscipk9 and WT plants (Figure 2D).
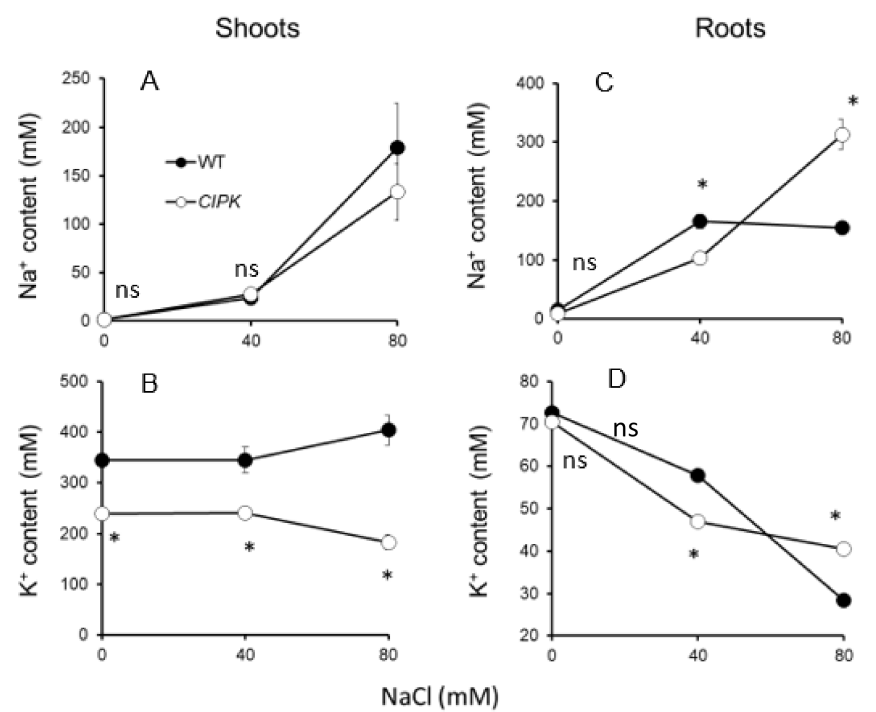

Figure 2. Effect of salinity on plant ionic composition. (A) shoot $\mathrm{Na}^{+}$content, (B) shoot $\mathrm{K}^{+}$content; (C) root $\mathrm{Na}^{+}$content; and (D) root $\mathrm{K}^{+}$content. Plants of both lines were grown in a hydroponic system for 21 days under three $\mathrm{NaCl}$ levels $(0,40$, and $80 \mathrm{mM} \mathrm{NaCl})$. Closed circles-WT; open circles-Oscipk 9 mutant line. Data are the mean $\pm \mathrm{SE}(n=6)$. Asterisk denotes significant difference between WT and cipk9 plants at $p<0.05$.

\subsection{Oscipk9 Mutant Performs Better under Osmotic Stress Conditions}

Oscipk 9 mutant experienced a stronger vegetative growth and produced a larger number of tillers (Figure $3 \mathrm{~A})$ resulting in a significantly $(\sim 40 \% ; p \leq 0.01)$ higher dry weight (compared with WT) in plants grown under control conditions (Figure 3B).

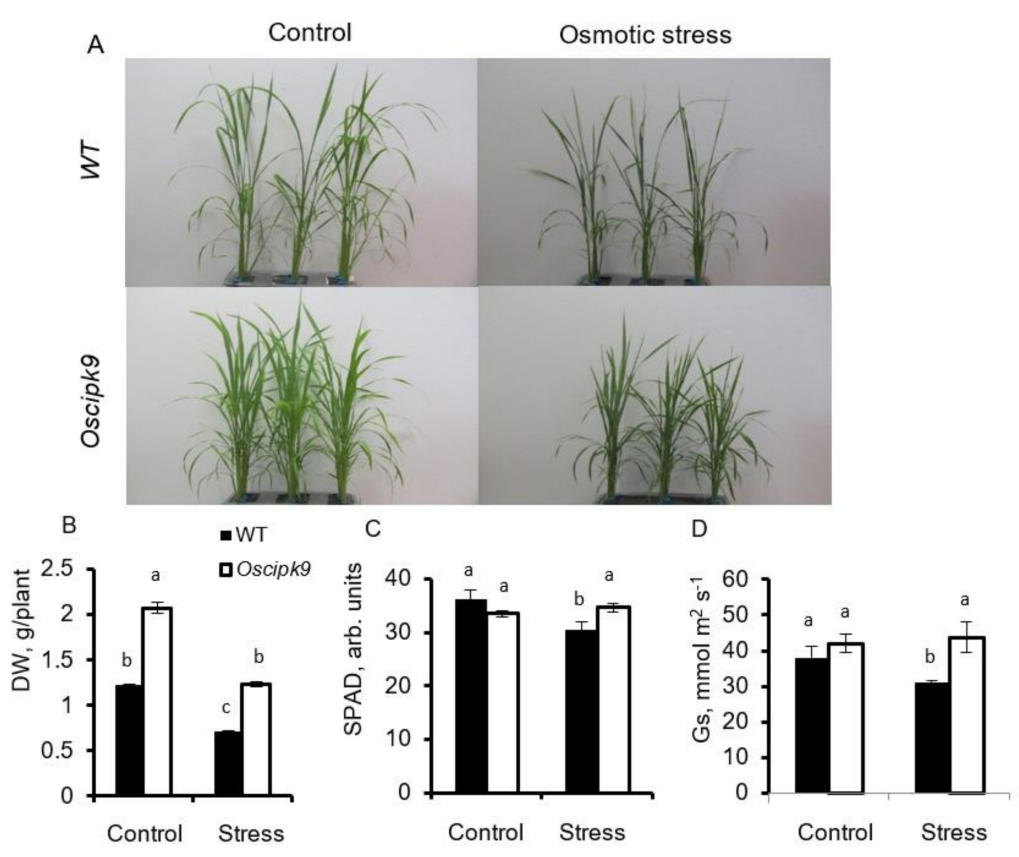

Figure 3. Effect of osmotic stress on growth and phenotype of Oscipk 9 and WT plants. Osmotic stress was induced by adding $11.8 \%(w / v)$ of PEG4000 (imposing an osmotic stress of $0.362 \mathrm{MPa}$ ) to the hydroponics growth solution. (A) plant phenotype; (B) plant dry weight; (C) chlorophyl content (SPAD values); and (D) stomatal conductance. Closed bars-WT; open bars-Oscipk9 mutant line. Data are the mean $\pm \operatorname{SE}(n=18)$. Data labelled with different low-case letters is significantly different at $p<0.05$. 
No significant (at $p<0.0)$ difference was reported for either leaf chlorophyll content (SPAD values; Figure 3C) or stomatal conductance (Figure 3D) between two lines under control conditions. Osmotic stress (PEG treatment) reduced plant DW in both lines by $\sim 40 \%$, with no significant $(p<0.05)$ difference in relative DW changes between the lines (Figure 3B). Chlorophyll content and stomatal conductance decreased slightly in WT but not Oscipk9 plants (Figure 3C,D, respectively). Shoot $\mathrm{Na}^{+}$and $\mathrm{K}^{+}$contents have both increased under drought conditions in WT, but remained unchanged in Oscipk9 mutant (Figure $4 \mathrm{~A}, \mathrm{~B}$ ). In roots, osmotic stress reduced $\mathrm{Na}^{+}$content slightly in both lines (Figure $4 \mathrm{C}$ ), while $\mathrm{K}^{+}$content remained unchanged in WT but declined in stress-exposed Oscipk9 plants (Figure 4D).
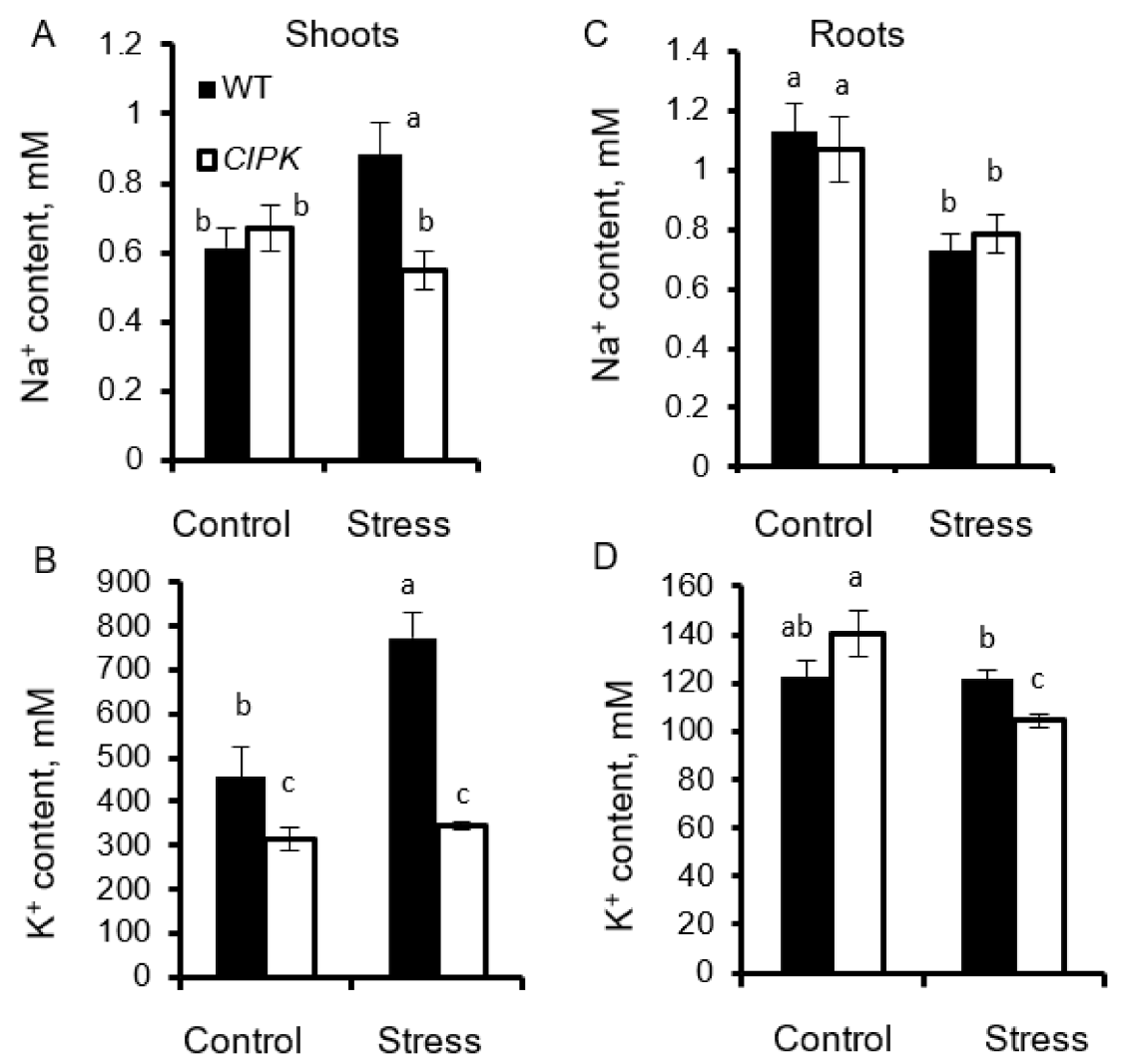

Figure 4. Effect of osmotic stress on plant ionic composition. (A) shoot $\mathrm{Na}^{+}$content, (B) shoot $\mathrm{K}^{+}$content; (C) root $\mathrm{Na}^{+}$content; and (D) root $\mathrm{K}^{+}$content. Plants of both lines were grown in a hydroponic system for 21 days and treated with PEG4000. Closed bars-WT; open bars-Oscipk9 mutant line. Data are the mean $\pm \mathrm{SE}(n=6)$. Data labelled with different low-case letters is significantly different at $p<0.05$.

\subsection{Oscipk9 Mutant Is More Sensitive to Low $\mathrm{K}^{+}$Availability}

Low $\mathrm{K}^{+}$availability came with the penalty to Oscipk9 mutant growth as compared to WT while these plants were more responsive to high $\mathrm{K}^{+}$(Figure 5A). No significant effects of $\mathrm{K}^{+}$availability on stomatal conductance were found (Figure 5B). Shoot $\mathrm{Na}^{+}$content remained unchanged regarding $\mathrm{K}^{+}$availability in $\mathrm{WT}$, but increased under conditions of $\mathrm{K}$ deficiency in Oscipk9 mutant (Figure 5C). Root $\mathrm{Na}^{+}$content decreased dramatically in both lines under luxury $\mathrm{K}^{+}$supply (Figure $5 \mathrm{E}$ ). Shoot $\mathrm{K}^{+}$content has increased by increasing $\mathrm{K}^{+}$availability in WT but remained unchanged in Oscipk9 mutant (Figure 5D), and $\mathrm{K}^{+}$ content was consistently higher in WT. In roots, plants grown under low- $\mathrm{K}^{+}$conditions had significantly $(p<0.05)$ less $\mathrm{K}^{+}$(Figure $\left.5 \mathrm{~F}\right)$, with the lowest $\mathrm{K}^{+}$content reported in WT plants. 
A
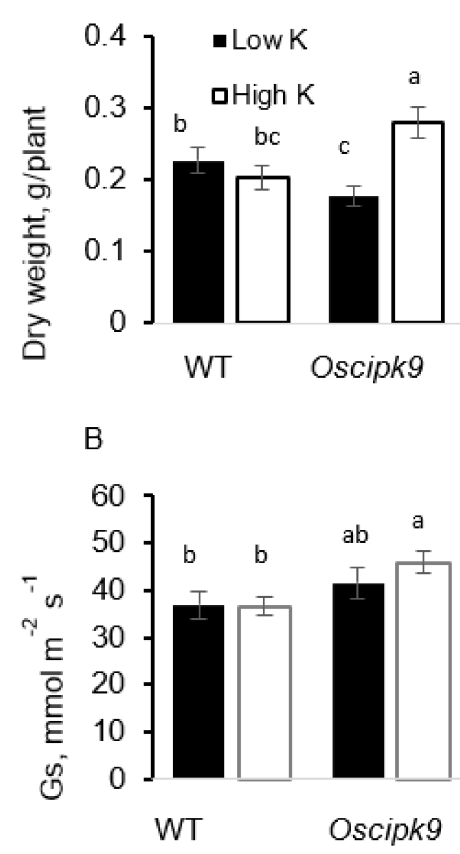

$\mathrm{C}$

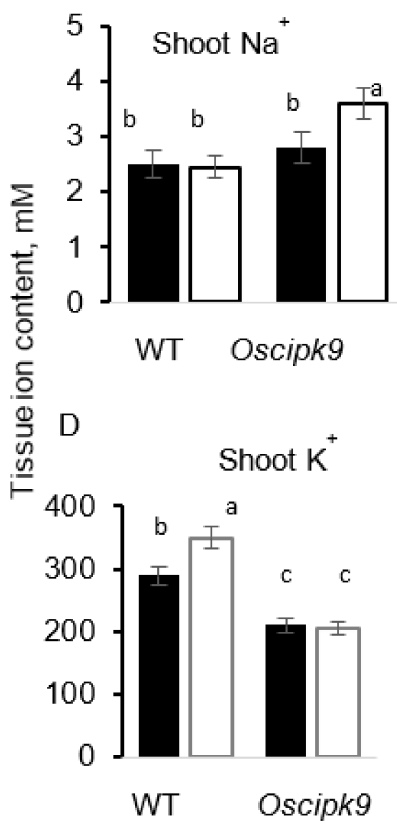

$\mathrm{E}$
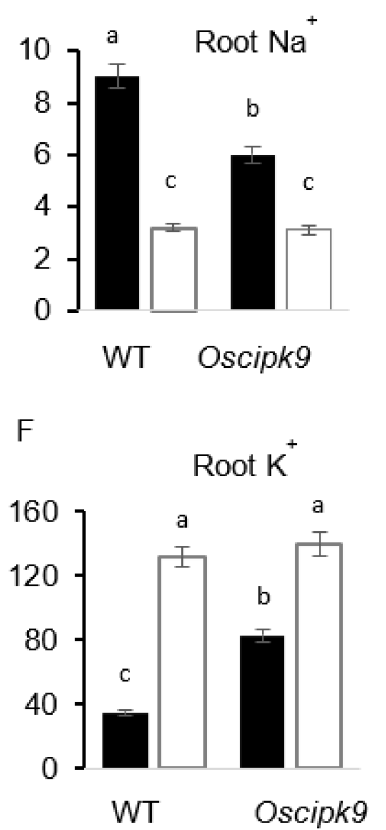

Figure 5. Effects of two $\mathrm{K}^{+}$availability on agronomical and physiological characteristics of WT Oscipk9 mutant plants. (A) plant dry weight; (B) stomatal conductance; (C) shoot $\mathrm{Na}^{+}$content; (D) shoot $\mathrm{K}^{+}$content; (E) root $\mathrm{Na}^{+}$content; and (F) root $\mathrm{K}^{+}$content. Closed bars-WT; open barsOscipk9 mutant line. Data are the mean \pm SE $(n=18)$. Data labelled with different low-case letters is significantly different at $p<0.05$.

\subsection{Roots of Oscipk9 Mutant Are More Sensitive to $\mathrm{H}_{2} \mathrm{O}_{2}$}

Both salinity and osmotic stress results in overaccumulation of reactive oxygen species that may affect plant ionic homeostasis (hence, growth). These ROS are also known to interact with $\mathrm{Ca}^{2+}$ transport and signalling systems, forming so-called "ROS-Ca ${ }^{2+} \mathrm{Hub}^{\text {" [42] }}$ by forming a feedback loop between $\mathrm{Ca}^{2+}$-permeable plasma membrane channels and NADPH oxidase that generates apoplastic ROS. Given the important role of CIPKs in $\mathrm{Ca}^{2+}$ signalling, we have compared the differences in kinetics of ROS-induced net $\mathrm{Ca}^{2+}$ and $\mathrm{K}^{+}$ fluxes between Oscipk9 and WT plants under conditions of various $\mathrm{K}^{+}$and $\mathrm{Ca}^{2+}$ availability.

Oxidative stress ( $5 \mathrm{mM} \mathrm{H}_{2} \mathrm{O}_{2}$ treatment) triggered massive $\mathrm{K}^{+}$loss from plant roots under low- $\mathrm{K}^{+}$conditions (Figure $6 \mathrm{~A}, \mathrm{~B}$ ); this loss was much more pronounced in Oscipk9 mutant (about 2-fold stronger net $\mathrm{K}^{+}$efflux; significant at $p<0.05$ ). In WT, these responses were independent of $\mathrm{Ca}^{2+}$ availability, while in the mutant, low $\mathrm{Ca}^{2+}$ availability increased sensitivity of ROS-activated $\mathrm{K}^{+}$-permeable channels to $\mathrm{H}_{2} \mathrm{O}_{2}$. Under luxury $\mathrm{K}^{+}$supply $(10 \mathrm{mM}) \mathrm{H}_{2} \mathrm{O}_{2}$ treatment did not cause any net $\mathrm{K}^{+}$loss (Figure $6 \mathrm{C}, \mathrm{D}$ ) but instead triggered a shift towards increased $\mathrm{K}^{+}$uptake. No significant (at $\left.p<0.05\right)$ effects of $\mathrm{Ca}^{2+}$ availability were detected in this case.

ROS treatment has resulted in an increased $\mathrm{Ca}^{2+}$ uptake in plant roots (Figure 7). No significant difference was found between ROS-induced $\mathrm{Ca}^{2+}$ flux responses under conditions of high- $\mathrm{K}^{+}$supply (Figure $7 \mathrm{C}, \mathrm{D}$ ), while under low- $\mathrm{K}^{+}$conditions, Oscipk9 mutant was more sensitive to ROS treatment (Figure 7A,B). 


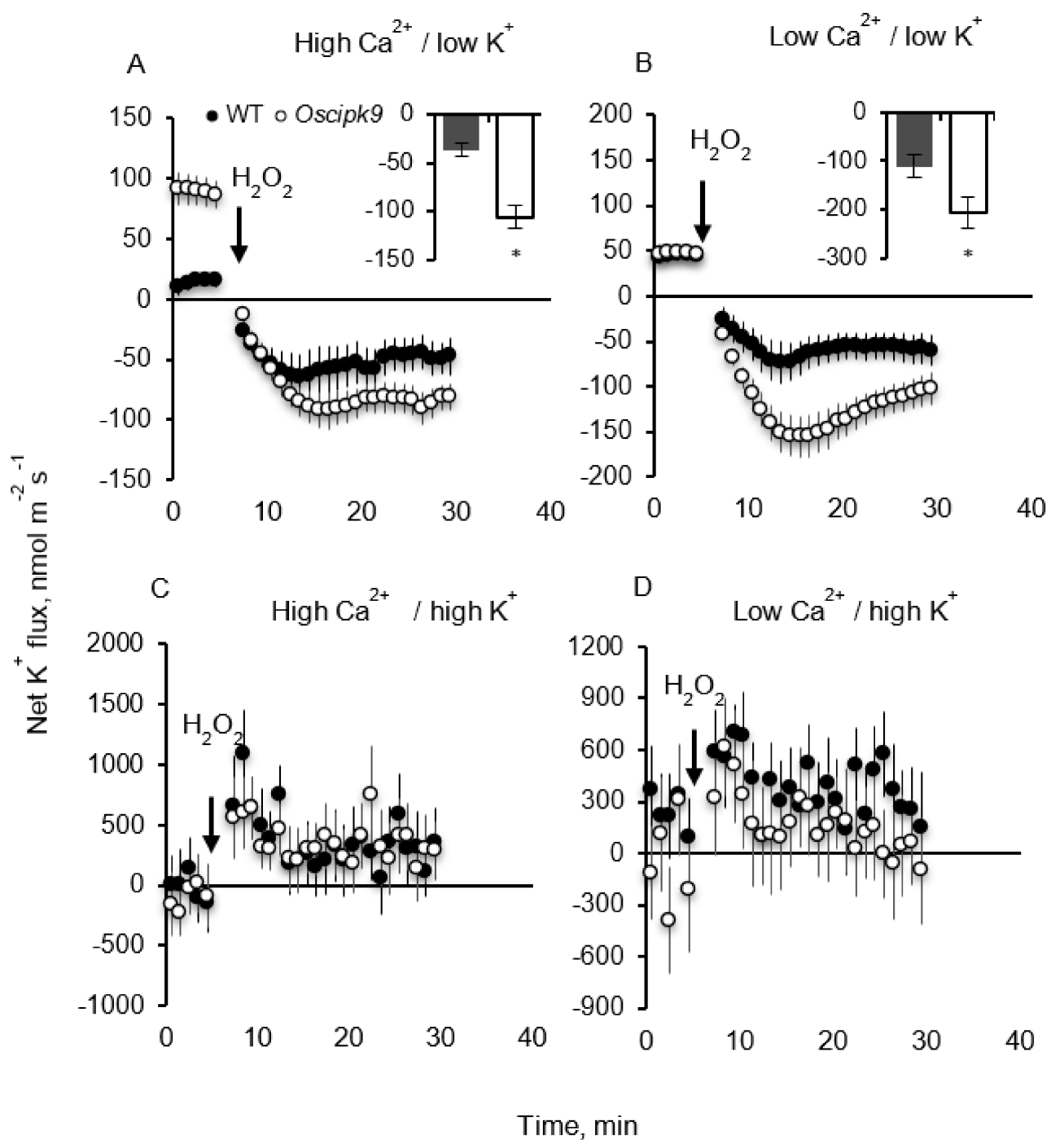

Figure 6. Effect of $\mathrm{K}^{+}$and $\mathrm{Ca}^{2+}$ availability on kinetics of ROS-induced net $\mathrm{K}^{+}$efflux measured from epidermal mature root cells of Oscipk9 mutant and its WT. ROS stress was imposed by adding $5 \mathrm{mM}$ $\mathrm{H}_{2} \mathrm{O}_{2}$ to 5-6-day-old seedlings. (A) high Ca/low $\mathrm{K}(1.5 \mathrm{mM} / 0.1 \mathrm{mM})$ conditions; (B) low Ca/low $\mathrm{K}(0.1 \mathrm{mM} / 0.1 \mathrm{mM})$ conditions; (C) high Ca/high $\mathrm{K}(1.5 \mathrm{mM} / 10 \mathrm{mM})$ conditions; and (D) low $\mathrm{Ca} /$ high $\mathrm{K}(0.1 \mathrm{mM} / 10 \mathrm{mM})$ conditions. Data are the mean $\pm \mathrm{SE}(n=6)$. The sign convention is "efflux negative". The inserts in the top two panels depict the magnitude of responses in each line. The sign convention is "efflux negative". The inserts in the top two panels depict the magnitude of responses in each line. Open symbols-Oscipk9; closed symbols-WT. Asterisk denotes significant difference between WT and cipk9 plants at $p<0.05$. 


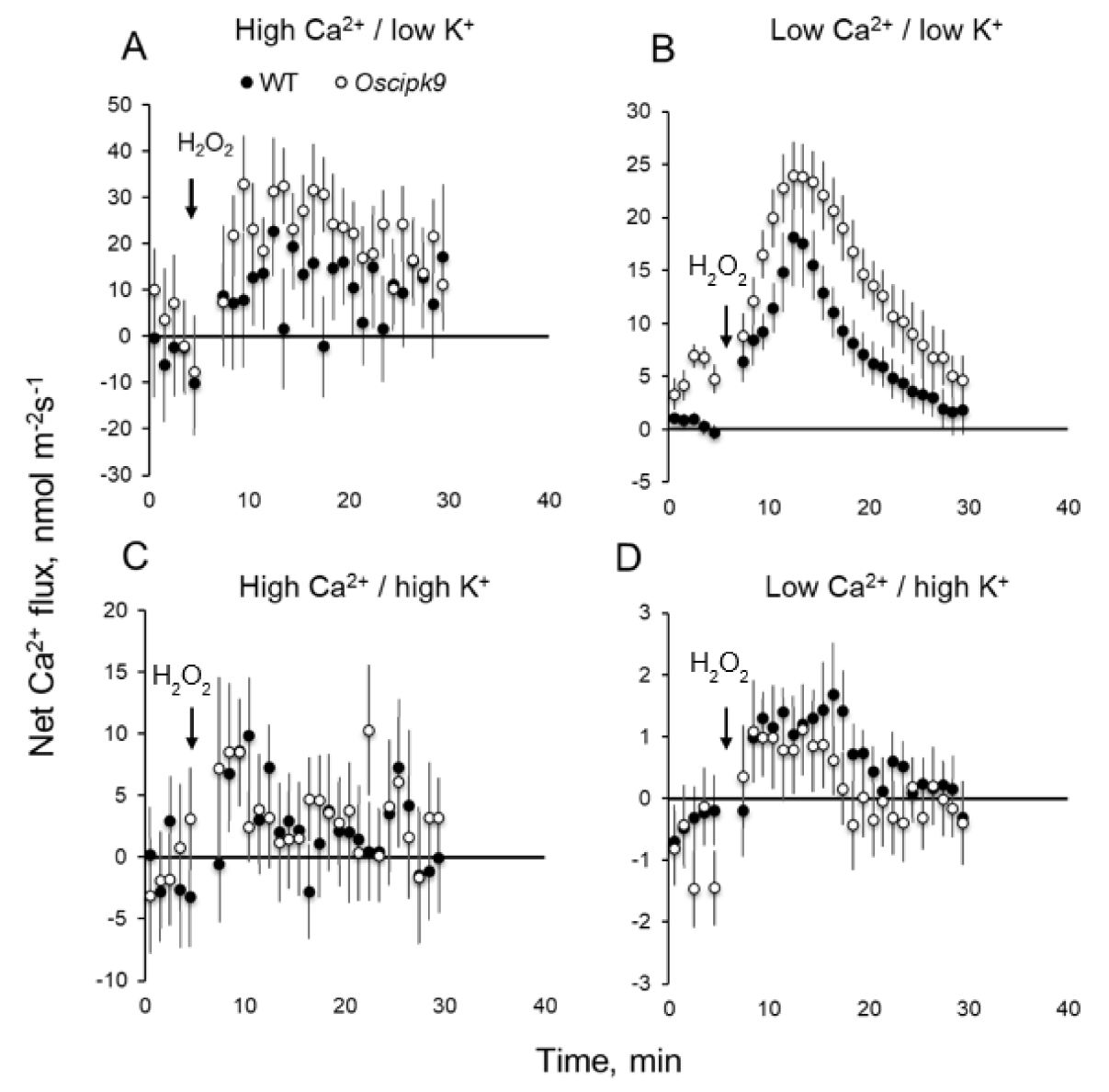

Figure 7. Effect of $\mathrm{K}^{+}$and $\mathrm{Ca}^{2+}$ availability on kinetics of ROS-induced net $\mathrm{Ca}^{2+}$ fluxes measured from epidermal mature root cells of Oscipk9 mutant and its WT. ROS stress was imposed by adding $5 \mathrm{mM} \mathrm{H}_{2} \mathrm{O}_{2}$ to 5-6-day-old seedlings. (A) high $\mathrm{Ca} /$ low $\mathrm{K}(1.5 \mathrm{mM} / 0.1 \mathrm{mM})$ conditions; (B) low $\mathrm{Ca} /$ low $\mathrm{K}(0.1 \mathrm{mM} / 0.1 \mathrm{mM})$ conditions; (C) high $\mathrm{Ca} /$ high $\mathrm{K}(1.5 \mathrm{mM} / 10 \mathrm{mM})$ conditions; and (D) low Ca/high K (0.1 mM/10 mM) conditions. Open symbols-Oscipk9; closed symbols—WT.

\section{Discussion}

The CBL-CIPK interacting complexes transduce various developmental and adaptive signals to downstream effectors, thus mediating plants responses to environment. In this work, we have shown that the loss of function in CIPK9 gene resulted in a mildly salt- and osmotic-stress-tolerant phenotype in rice. Oscipk9 plants accumulated less $\mathrm{K}^{+}$ in the shoot (Figure 4) but possessed higher stomatal conductance (Gs) (Figures 2 and 3). Oscipk9 roots also showed hypersensitivity to ROS under conditions of low $\mathrm{K}^{+}$availability (Figures 6 and 7).

\subsection{CIPK9 Is Essential for Stomata Operation under Stress Conditions}

The loss of functionality in CIPK9 has resulted in mildly salt- (Figure 1) and osmotic (Figure 3) stress-tolerant phenotypes in rice, which could be related to the ability of Oscipk9 plants to maintain higher Gs values (Figure 1C; Figure 3D) compared with WT; hence, they assimilate more carbon under conditions of reduced water availability.

Stomata represent the microscopic sphincters on the leaf surface that balance $\mathrm{CO}_{2}$ intake and water loss [43], and the ability of a plant to optimise stomatal aperture is critical for adaptation to adverse environmental conditions, especially salinity and drought [44]. Each stoma consists of a pair of guard cells, and its aperture is regulated by changes in the guard cell turgor mediated by rapid fluxes of ions into or out of cell [45]. This is 
achieved by sensing and transducing numerous environmental and internal signals. In the latter case, ABA is arguably the most prominent second messenger controlling stomata aperture [46,47]. It was shown that halophytic and glycophytic species (contrasting in their salinity stress tolerance), possess different baseline ABA levels, and that halophyte stomata are more sensitive to the fluctuation in ABA content in leaf mesophyll [45].

Early studies have suggested that cipk9-1, a null mutant of CIPK9, was hypersensitive to ABA during seed germination [48,49]. More recently, Lu et al. [50] have shown that overexpression of NtCIPK9 from Nitraria tangutorum in Arabidopsis resulted in a higher germination rate in the presence of $\mathrm{NaCl}$, and they attributed this effect to the regulation of endogenous ABA levels in plants. These findings suggest a causal link between CIPK9 operation and ABA production/signalling that could potentially explain higher Gs values in stress-exposed Oscipk9 plants in our study. It has been shown [51] that the functional loss of the CBL2/3-CIPK9/17 complex in Arabidopsis guard cells resulted in ABA hypersensitive stomatal closure and enhanced drought tolerance. This hypersensitive response was attributed to rapid modulation of potassium homeostasis at the tonoplast, presumably via activity of $\mathrm{NHX} \mathrm{K}\left(\mathrm{Na}^{+}\right) / \mathrm{H}^{+}$exchangers [51] although no supportive evidence was presented. More recently, Tang and co-authors demonstrated that CIPK9 preferentially phosphorylates two of its CBL partners, CBL2 and CBL3, and regulates TPK (two-pore potassium) vacuolar channels involved in remobilization of $\mathrm{K}^{+}$from the vacuole [52]. Taken together, the data suggests that the higher Gs values and mildly tolerant phenotype of Oscipk9 plants under water-limiting conditions may be a result of the negative regulation of tonoplast $\mathrm{K}^{+}$channels in guard cell vacuoles by CIPK9-CBL2/CBL3 complex, downstream of stress-induced ABA signalling.

\subsection{CIPK9 Is Essential for Rice Responses to Low $\mathrm{K}^{+}$Availability}

Plant $\mathrm{K}^{+}$acquisition is mediated by several low- and high-affinity uptake systems; of these, AKT1 inward-rectifying $\mathrm{K}^{+}$channels and high affinity $\mathrm{HAK} 5 \mathrm{~K}^{+}$transporters are considered to be critical [29]. Both are located at the plasma membrane and activated by CBL-CIPK complexes [53], specifically by CIPK23-CBL1/CBL9 [6,54]. Upon interaction with one of these CBLs, CIPK23 is recruited to the plasma membrane phosphorylates AKT1 $\mathrm{K}^{+}$channel, so that AKT1-mediated root $\mathrm{K}^{+}$uptake is enhanced [54].

CIPK9 is also known as a regulator of $\mathrm{K}^{+}$deficiency [55], and the growth of Atcipk9 mutants was negatively affected at low $(0.01 \mathrm{mM}) \mathrm{K}^{+}$availability suggesting that CIPK9 may function in plant adaptation to $\mathrm{K}^{+}$starvation [33]. Arabidopsis plants lacking CIPK9 displayed a tolerant phenotype to low-K stress, and it was shown that CIPK9 interacts with the calcium sensors CBL3 and CBL2 to regulate plant adaptive responses to $\mathrm{K}^{+}$ starvation $[38,56]$. Here, we show that the loss of CIPK9 in rice also compromises plant growth under conditions of low- but not high-K availability (Figure 5A). Thus, although CIPK orthologs from different species can have various roles [50], the essential role of CIPK9 in plant adaptation to $\mathrm{K}^{+}$starvation is preserved amongst multiple species.

\subsection{CIPK9 Control over $\mathrm{K}^{+}$Translocation and Compartmentalization}

Recently, Tang et al. [52] showed that, although $c b l 2 c b l 3$ double mutant plants were extremely sensitive to low-K levels in the medium, they exhibited a significantly higher $\mathrm{K}$ content as compared with the wild type, particularly under low-K conditions. These findings suggest that it is $\mathrm{K}^{+}$homeostasis, but not uptake per se, that may be affected by CBL-CIPK interacting complex, suggesting a likely role of CIPK9 in $\mathrm{K}^{+}$translocation between shoots and roots, especially under low-K conditions [36]. Consistent with these suggestions are our findings that while shoot $\mathrm{K}^{+}$was not different between Oscipk9 plants grown under low- and high-K conditions (Figure 5D), a nearly two-fold difference was observed in plant roots (Figure 5F). It was suggested earlier that the overexpression of CIPK9, CBL2, and CBL3 may impair root $\mathrm{K}^{+}$uptake from the environment [36]; thus, our observation of higher root $\mathrm{K}^{+}$content in the mutant plants lacking functional CIPK9 gene (Figure 5F) are consistent with those reports. 
In a stark contrast to CIPK23, that is localized predominantly at the plasma membrane, CIPK9 is associated with a tonoplast [6] and, hence, controls plant $\mathrm{K}^{+}$homeostasis by regulating its transport between vacuolar and cytosolic compartments. Salinity stress results in a massive $\mathrm{K}^{+}$loss from the root cytosol mediated by a range of depolarizationand ROS-activated $\mathrm{K}^{+}$channels $[28,57]$. To maintain normal metabolic activity, this cytosolic $\mathrm{K}^{+}$depletion needs to be buffered, at the expense of the vacuolar pool, until plants activate additional $\mathrm{K}^{+}$uptake systems, to regain lost $\mathrm{K}^{+}$[29]. The vacuolar $\mathrm{K}^{+}$pool reserves are estimated to maintain cytosolic $\mathrm{K}^{+}$homeostasis for $\sim 6 \mathrm{~h}$ [28] but need to be precisely regulated. Recently, Tang et al. [52] identified vacuolar TPK (two-pore $\mathrm{K}^{+}$) channels as a key player in this process in Arabidopsis and reported their regulation by CBL-CIPK interaction. Four CIPKs-CIPK3, 9, 23, and 26-were identified as partners of CBL2 and CBL3 that together regulate $\mathrm{K}^{+}$homeostasis through activating vacuolar $\mathrm{K}^{+}$efflux to the cytoplasm [52]. We believe that a similar scenario may be applicable to rice plants as well.

\subsection{The Loss of Function of OsCIPK9 Results in a Hypersensitivity to ROS under Conditions of} $K^{+}$Deficiency

Stress-induced calcium "signatures" are crucial for activation of plant adaptive cascades [3] and CBL-CIPK complexes operate as downstream $\mathrm{Ca}^{2+}$ sensors in this regulation $[6,53]$. As a result, activation of $\mathrm{K}^{+}$uptake systems is tightly regulated by $\mathrm{Ca}^{2+}$ (e.g., AKT1 by CBL1-CIPK23 [56,58]). Previous studies on Arabidopsis showed that CIPK9 did not interact with any major plasma membrane-based $\mathrm{K}^{+}$transporters such as AKT1, HAK5, AKT2, or SKOR [33]. However, whole-plant phenotypic observations are prone to possible misinterpretation, due to the functional redundancy of various CBL-CIPK members. Cell-based phenotyping offers better insights into mechanistic roles of plant kinases as regulators of membrane transport processes.

Both salinity and drought stresses result in accumulation of ROS species in plant tissues. Stress-induced ROS production is also reported in response to a broad range of other abiotic and biotic stresses. In this study, we showed that roots of Oscipk9 also showed hypersensitivity to ROS under conditions of low $\mathrm{K}^{+}$availability with a two-fold difference in the magnitude of $\mathrm{H}_{2} \mathrm{O}_{2}$-induced $\mathrm{K}^{+}$efflux between mutant and WT plants (Figure 6). This difference disappeared when plants were exposed to adequate $\mathrm{K}^{+}$supply. Consistent with these observations, also significant was the difference in the magnitude of ROS-induced $\mathrm{Ca}^{2+}$ fluxes between WT and Oscipk9 roots (Figure 7) under low-K conditions. These results imply that the loss of function of OsCIPK9 results in a hypersensitivity to ROS and implements $\mathrm{H}_{2} \mathrm{O}_{2}$ signalling as a component of plant adaptive responses to low-K environment.

ROS and $\mathrm{Ca}^{2+}$ signals interact in a positive feedback manner forming self-amplifying loops composed of NADPH oxidase (encoded by $\mathrm{RBOH}$ genes) and ROS-activated $\mathrm{Ca}^{2+}$ channels [42]. Plants grown under conditions of $\mathrm{K}^{+}$starvation possess higher basal levels of $\mathrm{H}_{2} \mathrm{O}_{2}$ [59], so activation of a " $\mathrm{Ca}^{2+}-\mathrm{NADPH}$ hub" will be more pronounced and rapid in this case. This is reflected in a bigger magnitude of ROS-induced $\mathrm{Ca}^{2+}$ uptake and $\mathrm{K}^{+}$loss in low-K grown plants. The higher sensitivity of Oscipk9 plants to $\mathrm{H}_{2} \mathrm{O}_{2}$ stimulation may be related either to the disturbance in $\mathrm{Ca}^{2+}$ sensing process or a possible role of CIPK9 in regulation of NADPH oxidase activity. The specific details of this process are the subject of separate studies. It should be also kept in mind that $\mathrm{H}_{2} \mathrm{O}_{2}$ is not the only ROS species produced in response to abiotic stresses. Other ROS types, such as superoxide or hydroxyl radicals, are also produced in various intracellular compartments, and might affect plant metabolism. In this context, understanding the role of CIPK9 in regulation of plant redox homeostasis and signalling warrants a separate investigation.

\section{Materials and Methods}

\subsection{Plant Material and Growth Conditions}

Seeds of rice plants, Oryza sativa L. Japonica cv Dongjin wild type, and its mutant Oscipk9, were obtained from Dr Chang-deok Han (National Institute of Agricultural 
Biotechnology, Seoul, Korea) and described in detail elsewhere [40]. Seeds were surfacesterilised with $1 \% v / v$ sodium hypochlorite (commercial bleach) for $10 \mathrm{~min}$, and then thoroughly rinsed with sterile deionised water at least five times. Seeds were sown in sand, and then incubated at $28{ }^{\circ} \mathrm{C}$ and $100 \%$ relative humidity, and kept in darkness for five days, until germination. The seedlings were then transferred to a 5-litre hydroponic system, consisting of a number of light-tight black plastic containers, each holding 9 plants. Hoagland solution was used as the growth medium $\left(1.25 \mathrm{mM} \mathrm{KNO}_{3} ; 0.5 \mathrm{mM} \mathrm{Ca}\left(\mathrm{NO}_{3}\right)_{2}\right.$,

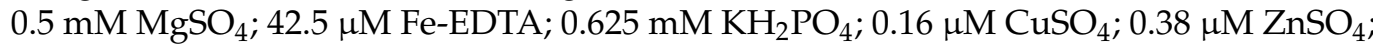
$1.8 \mu \mathrm{M} \mathrm{MnSO}_{4} ; 45 \mu \mathrm{M} \mathrm{H}_{3} \mathrm{BO}_{3} ; 0.015 \mu \mathrm{M}\left(\mathrm{NH}_{4}\right)_{2} \mathrm{MO}_{7} \mathrm{O}_{24} ;$ and $0.01 \mu \mathrm{M} \mathrm{CoCl}_{2}(\mathrm{pH} 5.5-6.0)$ ). Containers were placed into a climate-controlled glasshouse that was set on a light/dark cycle of $16 / 8 \mathrm{~h}$ and a day/night temperature of $28 / 20^{\circ} \mathrm{C}$, and relative humidity of $\sim 80 \%$. Two mercury vapour lamps $(2 \times 400 \mathrm{~W})$ were set to provide 16 -h days. The experiment design was a randomised block design with three replicates, with each container (replicate) holding nine plants for each treatment. The nutrient solution was changed every seven days. The rice seedlings were exposed to different abiotic stress conditions for 3 weeks, as described below. Experiments were conducted twice, with consistent results.

\subsection{Treatments}

Three types of experiments were conducted to study the effect of loss of function of Oscipk9 on plant's growth and development, under various environmental conditions. Firstly, eleven-day-old seedlings were exposed to two levels of salinity (moderate stress, $40 \mathrm{mM}$; and severe stress, $80 \mathrm{mM} \mathrm{NaCl}$ ) for three weeks. In the second experiment, osmotic stress was implemented by addition of $11.8 \%(w / v)$ of polyethylene glycol 4000 (PEG4000) (isotonic to $80 \mathrm{mM} \mathrm{NaCl}$ ), imposing an osmotic stress of $0.362 \mathrm{MPa}$. All treatments lasted for 3 weeks.

\subsection{Whole-Plant Physiological Assessment}

Chlorophyll content and stomatal conductance were measured on six randomly selected youngest fully expanded leaves of each treatment. All measurements were taken on a sunny day between 11:00 am and 1:00 pm, to minimize the diurnal influences. The chlorophyll content was measured using a Minolta Chlorophyll Meter SPAD-502 (Konica Minolta, Osaka, Japan); a Decagon leaf porometer (Decagon Devices Inc., Pullman, WA, USA) was used for the stomatal conductance measurements. Plants were then harvested, and their fresh weight was measured. Plants were then dried at $65^{\circ} \mathrm{C}$ in a drier (Unitherm, Birmingham, UK) and their dry weight was recorded.

\subsection{Osmolality and Ion Content}

Leaf and root osmolality, and $\mathrm{K}^{+}$and $\mathrm{Na}^{+}$contents were determined using the freezethaw method. Harvested root samples were rinsed in $10 \mathrm{mM} \mathrm{CaCl}_{2}$ to remove the apoplastic $\mathrm{Na}^{+}$, then blotted dry on tissue paper. Next, the samples were placed into $1.5 \mathrm{~mL}$ microfuge tubes and stored at $-20^{\circ} \mathrm{C}$ for at least $24 \mathrm{~h}$. The samples were subsequently thawed, and the sap squeezed from the tissues using a pointed glass rod. A small portion $(10 \mu \mathrm{L})$ of these sap samples was used for osmolality determination using a vapour pressure osmometer (Vapo, Wescor Inc., Logan, UT, USA). The remainder of the sap samples were diluted $\times 100$ times with distilled water and $\mathrm{K}^{+}$and $\mathrm{Na}^{+}$contents of the leaves and roots were measured using a flame photometer (Model PFP7 flame photometer, Jenway, Bibby Scientific Ltd., Staffordshire ST15 0SA, UK).

\subsection{Non-Invasive Ion Flux Measurements}

Net $\mathrm{K}^{+}$and $\mathrm{Ca}^{2+}$ fluxes from roots were measured using the non-invasive MIFE microelectrode system (University of Tasmania, Hobart, Australia). All details on microelectrode fabrication and calibration, as well as the theory of MIFE ion flux measurements, are available from our previous publications $[60,61]$. Rice seeds were germinated inside an incubator set at $28{ }^{\circ} \mathrm{C}$ and $100 \%$ relative humidity. Four different combinations of 
potassium and calcium ions were used in the growth solution: low $\mathrm{K}^{+}(0.5 \mathrm{mM}) / \mathrm{high} \mathrm{Ca}^{2+}$ $(1.5 \mathrm{mM})$, low $\mathrm{K}^{+} /$low $\mathrm{Ca}^{2+}(0.1 \mathrm{mM})$, high $\mathrm{K}^{+}(50 \mathrm{mM}) /$ high $\mathrm{Ca}^{2+}$, and high $\mathrm{K}^{+} /$low Ca ${ }^{2+}$. Roots of uniform and healthy 5-6-day-old seedlings were chosen and carefully placed on the centre of a glass holder and fixed firmly with Parafilm strips on both sides to avoid root movement during the measurement. The glass holder was then placed inside the measuring chamber that was partially filled with the bathing medium, BSM (Basal Salts Medium), consisting of $200 \mu \mathrm{M} \mathrm{NaCl}, 100 \mu \mathrm{M} \mathrm{CaCl}_{2}$, and $200 \mu \mathrm{M} \mathrm{KCl}$. The $\mathrm{pH}$ level of the BSM solution was maintained at $\sim 5.6$. For conditioning, the roots were left in the bathing solution for approximately 30-60 min. The measuring chamber was then positioned on a microscope stage, and electrode tips aligned and positioned next to the root surface, at a distance of $50 \mu \mathrm{m}$. Basal net $\mathrm{Ca}^{2+}$ and $\mathrm{K}^{+}$fluxes were recorded for 5-7 min from the mature root epidermis (ca $10 \mathrm{~mm}$ from the root tip). Then, $5 \mathrm{mM}$ of $\mathrm{H}_{2} \mathrm{O}_{2}$ was administered to plants, and transient responses were recorded for another 25-30 min. The ion fluxes were then calculated using MIFEFLUX software, and the resulting data imported to an Excel spreadsheet for further analysis. To ensure consistency of results, plants were grown in several batches so data for each treatment came from plants grown in 3 or 4 batches (e.g., independent treatments).

\subsection{Statistical Analysis}

All data used in this paper are expressed as mean values \pm SE. The statistical significance of mean and standard error values was determined by the $t$-test at $p \leq 0.05$ using SPSS software version 20 (IBM support portal, Pullman, WA, USA).

\section{Conclusions}

The findings of this study revealed that the calcineurin B-like protein-interacting protein kinase 9 (CIPK9) is involved in regulation of $\mathrm{K}^{+}$homeostasis in rice plants, particularly under the $\mathrm{K}^{+}$-deficient condition. The loss of function of CIPK results in a hypersensitivity to ROS in plant roots and mild salt- and osmotic-stress-tolerant phenotypes, attributed to the better control of stomata. Understanding the downstream signalling pathway and the role of CIPK9 in the cross-talks between ROS and ABA signalling may be instrumental for engineering plants with improved salinity and drought tolerance, to reduce impact of climate-driven abiotic stresses of crop production and food security.

Author Contributions: Conceptualization, S.S., M.Z. and Z.-H.C.; methodology, L.S., J.B. and M.Y.; data acquisition, M.A. and S.S.; formal analysis, M.A., S.S. and J.B.; original draft preparation, M.A.; and writing review and editing, S.S., Z.-H.C. and G.V. All authors have read and agreed to the published version of the manuscript.

Funding: Department of Industry, Science, Energy and Resources (project AISRF48490) to SS. China National Distinguished Expert Project (WQ20174400441), grant 31961143001 for Joint Research Projects between Pakistan Science Foundation and National Natural Science Foundation, and Chinese National Natural Science Foundation (project 31870249).

Conflicts of Interest: The authors declare no conflict of interest. The funders had no role in the design of the study; in the collection, analyses, or interpretation of data; in the writing of the manuscript, or in the decision to publish the results.

\section{References}

1. Lourenço, T.F.; Barros, P.M.; Saibo, N.J.M.; Abreu, I.A.; Santos, A.P.; António, C.; Pereira, J.S.; Oliveira, M.M. Genomics of drought. In Plant Genomics and Climate Change; Edwards, D., Batley, J., Eds.; Springer: New York, NY, USA, 2016; pp. 85-135.

2. Mori, I.C.; Schroeder, J.I. Reactive oxygen species activation of plant $\mathrm{Ca}^{2+}$ channels. A signaling mechanism in polar growth, hormone transduction, stress signaling, and hypothetically mechanotransduction. Plant Physiol. 2004, 135, 702-708. [CrossRef]

3. Steinhorst, L.; Kudla, J. Calcium and reactive oxygen species rule the waves of signaling. Plant Physiol. 2013, 163, 471-485. [CrossRef] [PubMed]

4. Manishankar, P.; Wang, N.L.; Koster, P.; Alatar, A.A.; Kudla, J. Calcium signaling during salt stress and in the regulation of ion homeostasis. J. Exp. Bot. 2018, 69, 4215-4226. [CrossRef] [PubMed] 
5. Kudla, J.; Becker, D.; Grill, E.; Hedrich, R.; Hippler, M.; Kummer, U.; Parniske, M.; Romeis, T.; Schumacher, K. Advances and current challenges in calcium signaling. New Phytol. 2018, 218, 414-431. [CrossRef]

6. Tang, R.J.; Wang, C.; Li, K.L.; Luan, S. The CBL-CIPK calcium signaling network: Unified paradigm from 20 years of discoveries. Trends Plant Sci. 2020, 25, 604-617. [CrossRef] [PubMed]

7. Schmockel, S.M.; Garcia, A.F.; Berger, B.; Tester, M.; Webb, A.A.R.; Roy, S.J. Different NaCl-induced calcium signatures in the Arabidopsis thaliana ecotypes Col-0 and C24. PLoS ONE 2015, 10, e0117564. [CrossRef] [PubMed]

8. $\quad$ Laohavisit, A.; Richards, S.L.; Shabala, L.; Chen, C.; Colaço, R.D.D.R.; Swarbreck, S.M.; Shaw, E.; Dark, A.; Shabala, S.; Shang, Z.; et al. Salinity-induced calcium signaling and root adaptation in Arabidopsis rsequire the calcium regulatory protein annexin1. Plant Physiol. 2013, 163, 253-262. [CrossRef]

9. Aslam, M.; Fakher, B.; Jakada, B.H.; Zhao, L.H.; Cao, S.J.; Cheng, Y.; Qin, Y. Genome-wide identification and expression profiling of CBL-CIPK gene family in pineapple (Ananas comosus) and the role of AcCBL1 in abiotic and biotic stress response. Biomolecules 2019, 9, 293. [CrossRef]

10. Zou, J.J.; Li, X.D.; Ratnasekera, D.; Wang, C.; Liu, W.X.; Song, L.F.; Zhang, W.Z.; Wu, W.H. Arabidopsis CALCIUM-DEPENDENT PROTEIN KINASE8 and CATALASE3 function in abscisic acid-mediated signaling and $\mathrm{H}_{2} \mathrm{O}_{2}$ homeostasis in stomatal guard cells under drought stress. Plant Cell 2015, 27, 1445-1460. [CrossRef] [PubMed]

11. Zhang, H.F.; Liu, D.Y.; Yang, B.; Liu, W.Z.; Mu, B.B.; Song, H.X.; Chen, B.Y.; Li, Y.; Ren, D.T.; Deng, H.Q.; et al. Arabidopsis CPK6 positively regulates $\mathrm{ABA}$ signaling and drought tolerance through phosphorylating ABA-responsive element-binding factors. $J$. Exp. Bot. 2020, 71, 188-203. [CrossRef]

12. Huang, S.L.; Jiang, S.F.; Liang, J.S.; Chen, M. Roles of plant CBL-CIPK systems in abiotic stress responses. Turk. J. Bot. 2019, 43, 271-280. [CrossRef]

13. Singh, A.; Sagar, S.; Biswas, D.K. Calcium Dependent Protein Kinase, a versatile player in plant stress management and development. Crit. Rev. Plant Sci. 2017, 36, 336-352. [CrossRef]

14. Noman, M.; Aysha, J.; Ketehouli, T.; Yang, J.; Du, L.N.; Wang, F.W.; Li, H.Y. Calmodulin binding transcription activators: An interplay between calcium signalling and plant stress tolerance. J. Plant Physiol. 2021, 256. [CrossRef] [PubMed]

15. Delormel, T.Y.; Boudsocq, M. Properties and functions of calcium-dependent protein kinases and their relatives in Arabidopsis thaliana. New Phytol. 2019, 224, 585-604. [CrossRef] [PubMed]

16. Ormancey, M.; Thuleau, P.; Mazars, C.; Cotelle, V. CDPKs and 14-3-3 proteins: Emerging duo in signaling. Trends Plant Sci. 2017, 22, 263-272. [CrossRef]

17. Ranty, B.; Aldon, D.; Cotelle, V.; Galaud, J.P.; Thuleau, P.; Mazars, C. Calcium sensors as key hubs in plant responses to biotic and abiotic stresses. Front. Plant Sci. 2016, 7. [CrossRef] [PubMed]

18. Thoday-Kennedy, E.L.; Jacobs, A.K.; Roy, S.J. The role of the CBL-CIPK calcium signalling network in regulating ion transport in response to abiotic stress. Plant Growth Reg. 2015, 76, 3-12. [CrossRef]

19. Kolukisaoglu, U.; Weinl, S.; Blazevic, D.; Batistic, O.; Kudla, J. Calcium sensors and their interacting protein kinases: Genomics of the Arabidopsis and rice CBL-CIPK signaling networks. Plant Physiol. 2004, 134, 43-58. [CrossRef]

20. Weinl, S.; Kudla, J. The CBL-CIPK Ca ${ }^{2+}$-decoding signaling network: Function and perspectives. New Phytol. 2009, 184, 517-528. [CrossRef]

21. Xiang, Y.; Huang, Y.; Xiong, L. Characterization of stress-responsive CIPK genes in rice for stress tolerance improvement. Plant Physiol. 2007, 144, 1416-1428. [CrossRef]

22. Qiu, Q.S.; Guo, Y.; Dietrich, M.A.; Schumaker, K.S.; Zhu, J.K. Regulation of SOS1, a plasma membrane $\mathrm{Na}^{+} / \mathrm{H}^{+}$exchanger in Arabidopsis thaliana, by SOS2 and SOS3. Proc. Natl. Acad. Sci. USA 2002, 99, 8436-8441. [CrossRef] [PubMed]

23. Qiu, Q.S.; Guo, Y.; Quintero, F.J.; Pardo, J.M.; Schumaker, K.S.; Zhu, J.K. Regulation of vacuolar $\mathrm{Na}^{+} / \mathrm{H}^{+}$exchange in Arabidopsis thaliana by the salt-overly-sensitive (SOS) pathway. J. Biol. Chem. 2004, 279, 207-215. [CrossRef] [PubMed]

24. Cheng, N.-H.; Pittman, J.K.; Zhu, J.-K.; Hirschi, K.D. The protein kinase SOS2 activates the Arabidopsis $\mathrm{H}^{+} / \mathrm{Ca}^{2+}$ antiporter CAX1 to integrate calcium transport and salt tolerance. J. Biol. Chem. 2004, 279, 2922-2926. [CrossRef]

25. Martínez-Atienza, J.; Jiang, X.; Garciadeblas, B.; Mendoza, I.; Zhu, J.-K.; Pardo, J.M.; Quintero, F.J. Conservation of the salt overly sensitive pathway in rice. Plant Physiol. 2007, 143, 1001-1012. [CrossRef] [PubMed]

26. Rao, X.-L.; Zhang, X.-H.; Li, R.-J.; Shi, H.-T.; Lu, Y.-T. A calcium sensor-interacting protein kinase negatively regulates salt stress tolerance in rice (Oryza sativa). Funct. Plant Biol. 2011, 38, 441-450. [CrossRef]

27. Shabala, S.; Pottosin, I. Regulation of potassium transport in plants under hostile conditions: Implications for abiotic and biotic stress tolerance. Physiol. Plant. 2014, 151, 257-279. [CrossRef] [PubMed]

28. Wu, H.; Zhang, X.; Giraldo, J.P.; Shabala, S. It is not all about sodium: Revealing tissue specificity and signalling roles of potassium in plant responses to salt stress. Plant Soil 2018, 431, 1-17. [CrossRef]

29. Rubio, F.; Nieves-Cordones, M.; Horie, T.; Shabala, S. Doing 'business as usual' comes with a cost: Evaluating energy cost of maintaining plant intracellular $\mathrm{K}^{+}$homeostasis under saline conditions. New Phytol. 2020, 225, 1097-1104. [CrossRef]

30. Nieves-Cordones, M.; Caballero, F.; Martínez, V.; Rubio, F. Disruption of the Arabidopsis thaliana inward-rectifier $\mathrm{K}^{+}$channel AKT1 improves plant responses to water stress. Plant Cell Physiol. 2012, 53, 423-432. [CrossRef]

31. Li, J.; Long, Y.; Qi, G.N.; Li, J.; Xu, Z.J.; Wu, W.H.; Wang, Y. The Os-AKT1 channel is critical for $\mathrm{K}^{+}$uptake in rice roots and is modulated by the rice CBL1-CIPK23 complex. Plant Cell 2014, 26, 3387-3402. [CrossRef] 
32. Ragel, P.; Ródenas, R.; García-Martín, E.; Andrés, Z.; Villalta, I.; Nieves-Cordones, M.; Rivero, R.M.; Martínez, V.; Pardo, J.M.; Quintero, F.J.; et al. The CBL-interacting protein kinase CIPK23 regulates HAK5-mediated high-affinity $\mathrm{K}^{+}$uptake in Arabidopsis roots. Plant Physiol. 2015, 169, 2863-2873.

33. Pandey, G.K.; Cheong, Y.H.; Kim, B.G.; Grant, J.J.; Li, L.; Luan, S. CIPK9: A calcium sensor-interacting protein kinase required for low-potassium tolerance in Arabidopsis. Cell Res. 2007, 17, 411-421. [CrossRef] [PubMed]

34. Singh, A.; Yadav, A.K.; Kaur, K.; Sanyal, S.K.; Jha, S.K.; Fernandes, J.L.; Sharma, P.; Tokas, I.; Pandey, A.; Luan, S.; et al. A protein phosphatase $2 \mathrm{C}, \mathrm{AP} 2 \mathrm{C} 1$, interacts with and negatively regulates the function of CIPK9 under potassium-deficient conditions in Arabidopsis. J. Exp. Bot. 2018, 69, 4003-4015. [CrossRef] [PubMed]

35. Lara, A.; Rodenas, R.; Andres, Z.; Martinez, V.; Quintero, F.J.; Nieves-Cordones, M.; Botella, M.A.; Rubio, F. Arabidopsis K ${ }^{+}$ transporter HAK5-mediated high-affinity root $\mathrm{K}^{+}$uptake is regulated by protein kinases CIPK1 and CIPK9. J. Exp. Bot. 2020, 71, 5053-5060. [CrossRef]

36. Liu, L.L.; Ren, H.M.; Chen, L.Q.; Wang, Y.; Wu, W.H. A protein kinase, calcineurin B-like protein-interacting protein Kinase9, interacts with calcium sensor calcineurin B-like Protein3 and regulates potassium homeostasis under low-potassium stress in Arabidopsis. Plant Physiol. 2013, 161, 266-277. [CrossRef]

37. Costa, A.; Luoni, L.; Marrano, C.A.; Hashimoto, K.; Koster, P.; Giacometti, S.; De Michelis, M.I.; Kudla, J.; Bonza, M.C. Ca ${ }^{2+}$ dependent phosphoregulation of the plasma membrane $\mathrm{Ca}^{2+}$-ATPase ACA8 modulates stimulus-induced calcium signatures. J. Exp. Bot. 2017, 68, 3215-3230. [CrossRef] [PubMed]

38. Tang, R.J.; Zhao, F.G.; Garcia, V.J.; Kleist, T.J.; Yang, L.; Zhang, H.X.; Luan, S. Tonoplast CBL-CIPK calcium signaling network regulates magnesium homeostasis in Arabidopsis. Proc. Natl. Acad. Sci. USA 2015, 112, 3134-3139. [CrossRef] [PubMed]

39. Mogami, J.; Fujita, Y.; Yoshida, T.; Tsukiori, Y.; Nakagami, H.; Nomura, Y.; Fujiwara, T.; Nishida, S.; Yanagisawa, S.; Ishida, T.; et al. 2015 Two distinct families of protein kinases are required for plant growth under high external $\mathrm{Mg}^{2+}$ concentrations in Arabidopsis. Plant Physiol. 2015, 167, 1039-1057. [CrossRef] [PubMed]

40. Xuan, Y.H.; Kumar, V.; Han, X.; Kim, S.H.; Jeong, J.H.; Kim, C.M.; Gao, Y.; Han, C.D. CBL-INTERACTING PROTEIN KINASE 9 regulates ammonium-dependent root growth downstream of IDD10 in rice (Oryza sativa). Ann. Bot. 2019, 124, 947-960. [CrossRef] [PubMed]

41. Kanwar, P.; Sanyal, S.K.; Tokas, I.; Yadav, A.K.; Pandey, A.; Kapoor, S.; Pandey, G.K. Comprehensive structural, interaction and expression analysis of CBL and CIPK complement during abiotic stresses and development in rice. Cell Calcium 2014, 56, 81-95. [CrossRef]

42. Demidchik, V.; Shabala, S. Mechanisms of cytosolic calcium elevation in plants: The role of ion channels, calcium extrusion

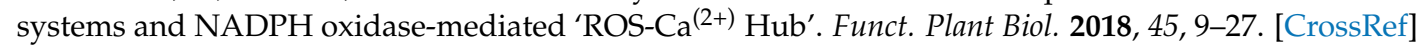

43. Lawson, T.; Matthews, J. Guard cell metabolism and stomatal function. Annu. Rev. Plant Biol. 2020, 71, 273-302. [CrossRef]

44. Shabala, S. Learning from halophytes: Physiological basis and strategies to improve abiotic stress tolerance in crops. Ann. Bot. 2013, 112, 1209-1221. [CrossRef]

45. Hedrich, R.; Shabala, S. Stomata in a saline world. Curr. Opin. Plant Biol. 2018, 46, 87-95. [CrossRef] [PubMed]

46. Buckley, T.N. How do stomata respond to water status? New Phytol. 2019, 224, 21-36. [CrossRef]

47. Postiglione, A.E.; Muday, G.K. The role of ROS homeostasis in ABA-induced guard cell signaling. Front. Plant Sci. 2020, 11, 968. [CrossRef]

48. Pandey, G.K.; Cheong, Y.H.; Kim, K.N.; Grant, J.J.; Li, L.; Hung, W.; D’Angelo, C.; Weinl, S.; Kudla, J.; Luan, S. The calcium sensor calcineurin B-like 9 modulates abscisic acid sensitivity and biosynthesis in Arabidopsis. Plant Cell 2004, 16, 1912-1924. [CrossRef] [PubMed]

49. Pandey, G.K.; Grant, J.J.; Cheong, Y.H.; Kim, B.-G.; Li, L.G.; Luan, S. Calcineurin-B-like protein CBL9 interacts with target kinase CIPK3 in the regulation of ABA response in seed germination. Mol. Plant 2008, 1, 238-248. [CrossRef] [PubMed]

50. Lu, L.; Chen, X.; Zhu, L.; Li, M.; Zhang, J.; Yang, X.; Wang, P.; Lu, Y.; Cheng, T.; Shi, J.; et al. NtCIPK9: A Calcineurin B-like protein-interacting protein kinase from the halophyte Nitraria tangutorum, enhances arabidopsis salt tolerance. Front. Plant Sci. 2020, 11, 1112. [CrossRef] [PubMed]

51. Song, S.J.; Feng, Q.N.; Li, C.L.; Li, E.; Liu, Q.; Kang, H.; Zhang, W.; Zhang, Y.; Li, S. A tonoplast-associated calcium-signaling module dampens ABA signaling during stomatal movement. Plant Physiol. 2018, 177, 1666-1678. [CrossRef]

52. Tang, R.J.; Zhao, F.G.; Yang, Y.; Wang, C.; Li, K.; Kleist, T.J.; Lemaux, P.G.; Luan, S. A calcium signalling network activates vacuolar $\mathrm{K}^{(+)}$remobilization to enable plant adaptation to low-K environments. Nat. Plants 2020, 6, 384-393. [CrossRef] [PubMed]

53. Luan, S. The CBL-CIPK network in plant calcium signaling. Trends Plant Sci. 2009, 14, 37-42. [CrossRef]

54. Xu, J.; Li, H.D.; Chen, L.Q.; Wang, Y.; Liu, L.L.; He, L.; Wu, W.H. A protein kinase, interacting with two calcineurin B-like proteins, regulates $\mathrm{K}^{+}$transporter AKT1 in Arabidopsis. Cell 2006, 125, 1347-1360. [CrossRef] [PubMed]

55. Yadav, A.K.; Jha, S.K.; Sanyal, S.K.; Luan, S.; Pandey, G.K. Arabidopsis calcineurin B-like proteins differentially regulate phosphorylation activity of CBL-interacting protein kinase 9. Biochem. J. 2018, 475, 2621-2636. [CrossRef]

56. Li, L.; Kim, B.-G.; Cheong, Y.H.; Pandey, G.K.; Luan, S. A Ca ${ }^{2+}$ signaling pathway regulates a $\mathrm{K}^{+}$channel for low-K response in Arabidopsis. Proc. Natl. Acad. Sci. USA 2006, 103, 12625-12630. [CrossRef]

57. Shabala, S.; Bose, J.; Fuglsang, A.T.; Pottosin, I. On a quest for stress tolerance genes: Membrane transporters in sensing and adapting to hostile soils. J. Exp. Bot. 2016, 67, 1015-1031. [CrossRef] 
58. Behera, S.; Long, Y.; Schmitz-Thom, I.; Wang, X.-P.; Zhang, C.; Li, H.; Steinhorst, L.; Manishankar, P.; Ren, X.-L.; Offenborn, J.N.; et al. Two spatially and temporally distinct $\mathrm{Ca}^{2+}$ signals convey Arabidopsis thaliana responses to $\mathrm{K}^{+}$deficiency. New Phytol. 2017, 213, 739-750. [CrossRef]

59. Shin, R.; Berg, R.H.; Schachtman, D.P. Reactive oxygen species and root hairs in Arabidopsis root response to nitrogen, phosphorus and potassium deficiency. Plant Cell Physiol. 2005, 46, 1350-1357. [CrossRef]

60. Shabala, S.N.; Newman, I.A.; Morris, J. Oscillations in $\mathrm{H}^{+}$and $\mathrm{Ca}^{2+}$ ion fluxes around the elongation region of corn roots and effects of external pH. Plant Physiol. 1997, 113, 111-118. [CrossRef]

61. Shabala, L.; Ross, T.; McMeekin, T.; Shabala, S. Non-invasive microelectrode ion flux measurements to study adaptive responses of microorganisms to the environment. FEMS Microbiol. Rev. 2006, 30, 472-486. [CrossRef] [PubMed] 